\title{
Greater Sage-Grouse and Severe Winter Conditions: Identifying Habitat for Conservation
}

\author{
Matthew R. Dzialak, ${ }^{1}$ Stephen L. Webb, ${ }^{2}$ Seth M. Harju, ${ }^{3}$ Chad V. Olson, ${ }^{4}$ Jeffrey B. Winstead, ${ }^{5}$ \\ and Larry D. Hayden-Wing ${ }^{6}$
}

Authors are ${ }^{1}$ Wildife Ecologist, ${ }^{2}$ Quantitative Ecologist, ${ }^{3}$ Wildife Biologist/Biometrician, ${ }^{4}$ Wildlife Biologist, ${ }^{5}$ Principle Biologist, and ${ }^{6}$ Retired, Hayden-Wing Associates LLC, Natural Resource Consultants, Laramie, WY 82070, USA.

\begin{abstract}
Developing sustainable rangeland management strategies requires solution-driven research that addresses ecological issues within the context of regionally important socioeconomic concerns. A key sustainability issue in many regions of the world is conserving habitat that buffers animal populations from climatic variability, including seasonal deviation from long-term precipitation or temperature averages, and that can establish an ecological bottleneck by which the landscape-level availability of critical resources becomes limited. We integrated methods to collect landscape-level animal occurrence data during severe winter conditions with estimation and validation of a resource selection function, with the larger goal of developing spatially explicit guidance for rangeland habitat conservation. The investigation involved greater sage-grouse (Centrocercus urophasianus) that occupy a landscape that is undergoing human modification for development of energy resources. We refined spatial predictions by exploring how reductions in the availability of sagebrush (as a consequence of increasing snow depth) may affect patterns of predicted occurrence. Occurrence of sage-grouse reflected landscape-level selection for big sagebrush, taller shrubs, and favorable thermal conditions and avoidance of bare ground and anthropogenic features. Refinement of spatial predictions showed that important severe winter habitat was distributed patchily and was constrained in spatial extent (7-18\% of the landscape). The mapping tools we developed offer spatially explicit guidance for planning human activity in ways that are compatible with sustaining habitat that functions disproportionately in population persistence relative to its spatial extent or frequency of use. Increasingly, place-based, quantitative investigations that aim to develop solutions to landscape sustainability issues will be needed to keep pace with human-modification of rangeland and uncertainty associated with global climate change and its effects on animal populations.
\end{abstract}

Key Words: energy development, greater sage-grouse, landscape planning, resource selection, severe winter conditions, sustainability

\section{INTRODUCTION}

Climatic seasonality, or within-year variability in precipitation and temperature (Williams and Middleton 2008), is a prominent feature of temperate rangelands. In regions with a pronounced winter season, climatic seasonality is gauged in terms of winter severity or deviation from long-term temperature and precipitation averages. For animal populations, periods of below-average temperature and above-average snow depth can reduce landscape-level availability of food resources or cover, causing the redistribution, and potentially concentration, of animals into spatially restricted patches where food and cover remain available (i.e., severe winter range; Moynahan et al. 2006; Sawyer et al. 2006). Thus, for many animal populations, severe winter conditions can establish an ecological bottleneck, with consequences for population persistence, by episodically limiting resource availability (Wiens 1977;

Research was funded by energy industry operators associated with the Continental Divide-Creston Environmental Impact Statement.

Correspondence: Matthew R. Dzialak, Hayden-Wing Associates LLC, Natural Resource Consultants, 2308 S 8th St, Laramie, WY 82070, USA. Email: matt@haydenwing.com Current address: Larry D. Hayden-Wing, P0 Box 1690, Laramie, WY 82073, USA.

Current address: Stephen L. Webb, Department of Scientific Computing, Samuel Roberts Noble Foundation, 2510 Sam Noble Parkway, Ardmore, OK 73401, USA.

Manuscript received 16 December 2011; manuscript accepted 19 June 2012.

(c) 2013 The Society for Range Management
Williams and Middleton 2008). The importance of identifying habitat that buffers populations against climatic variability has taken on new urgency because of increasing human modification of landscapes coupled with uncertainty associated with climate change; both of which have outpaced the acquisition of information necessary to develop sustainable strategies for conservation (Sawyer et al. 2009; McAlpine et al. 2010).

In this paper we apply a landscape-ecological approach to identifying habitat that functions in population persistence during conditions of limited resource availability. This approach included methods to collect landscape-level animal occurrence data during severe winter conditions and estimation and validation of a resource selection function (RSF; Manly et al. 2002). The investigation involved greater sage-grouse (Centrocercus urophasianus; hereafter sage-grouse) that occupy a landscape that is undergoing human modification for the development of energy resources. Sage-grouse are distributed throughout shrub-steppe habitat in 11 American states and two Canadian provinces and are strongly associated with several species of sagebrush (Artemisia spp.). Long-term ( 10-40 yr) population declines of $17-47 \%$ have been observed throughout much of the species distribution (Connelly and Braun 1997; Connelly et al. 2004; Fedy and Aldridge 2011). In 2010 listing of sage-grouse as federally threatened or endangered within the United States was found to be warranted under the Endangered Species Act, but listing was precluded by higher priority listing actions (U.S. Fish and Wildlife Service 2010). Sage-grouse tend 


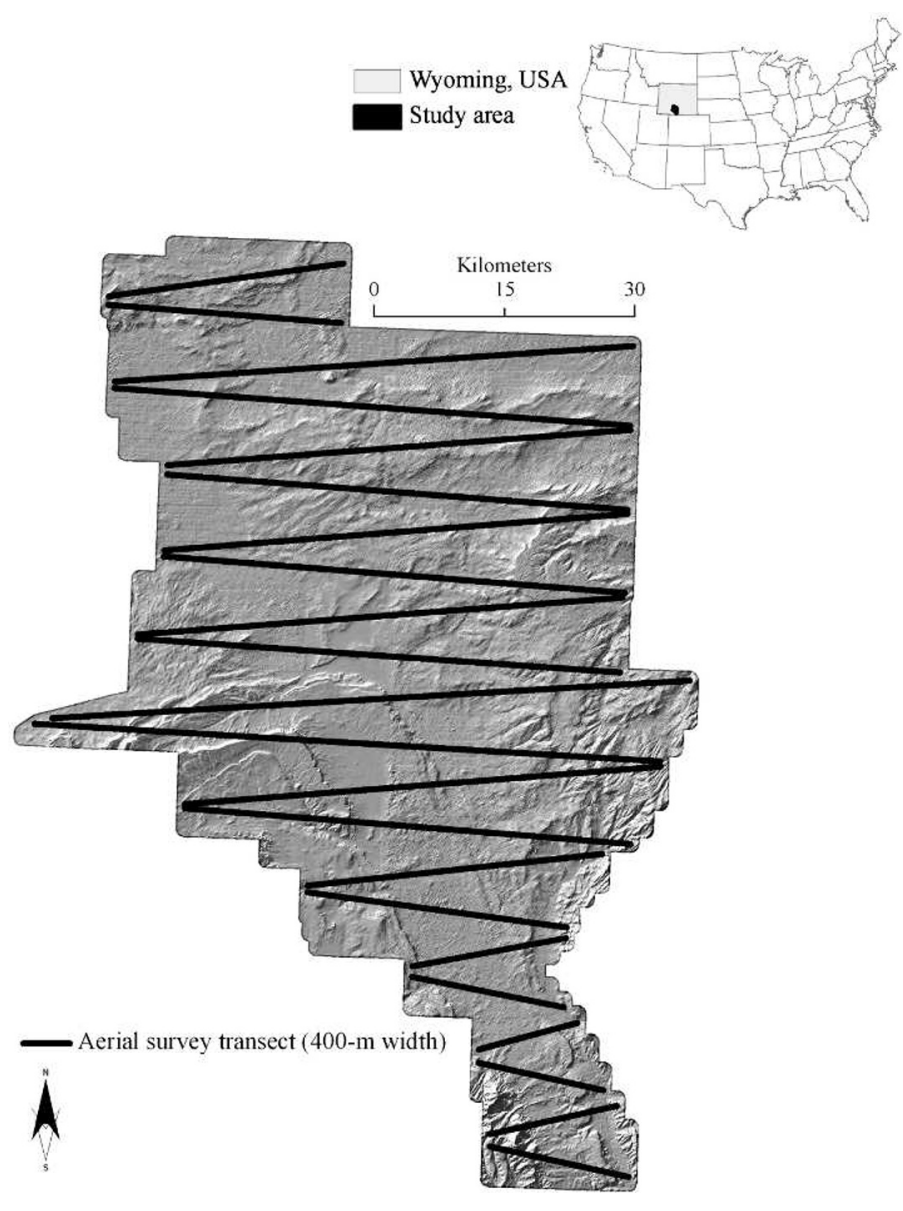

Figure 1. The $4328 \mathrm{~km}^{2}$ study area within the Great Divide Basin in southcentral Wyoming, USA, including 22 aerial survey transects arranged throughout the study area in a continuous zigzag design, buffered by $200 \mathrm{~m}$ on each side, and spaced at 9-km intervals.

to have a low overwinter mortality rate in average climatic conditions (Zablan et al. 2003; Connelly et al. 2004; Beck et al. 2006), but there is evidence that severe winter conditions can substantially increase mortality rate (Moynahan et al. 2006).

\section{METHODS}

\section{Study Area}

The $4328-\mathrm{km}^{2}$ study area included portions of the Great Divide Basin in south-central Wyoming, United States (Fig. 1). The terrain was characterized by rolling sagebrush steppe, gently sloping flats, vegetated sand dunes, and badland hills ranging in elevation from $1933 \mathrm{~m}$ to $2385 \mathrm{~m}$. Average maximum and minimum temperature during winter (1 November-31 March) is $1.7^{\circ} \mathrm{C}$ and $-10.9^{\circ} \mathrm{C}$, respectively; average monthly precipitation is $0.81 \mathrm{~cm}$ (Western Regional Climate Center 2011). Dominant vegetation included Wyoming big sagebrush (Artemisia tridentata wyomingensis), mountain big sagebrush (A. t. vaseyana), basin big sagebrush (A. t. tridentata), birdfoot sagebrush (Artemisia pedatifida), black greasewood (Sarcobatus vermiculatus), wheatgrass (Pseudoroegneria spp.), and fescue (Festuca spp.).

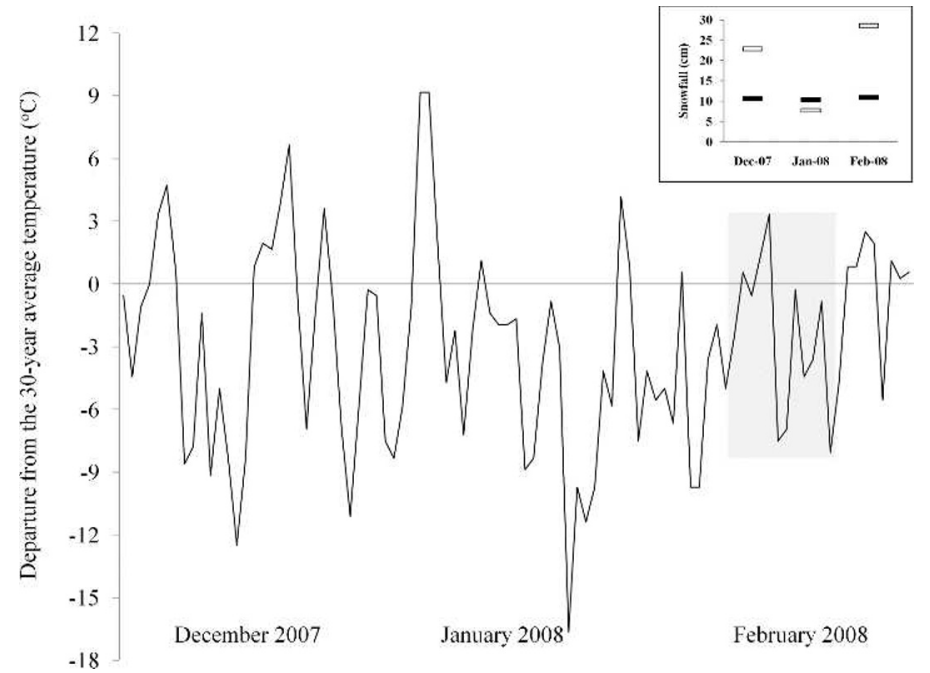

Figure 2. Departure from the $30-y r$ average temperature $\left({ }^{\circ} \mathrm{C}\right)$, and snowfall amount (inset) during December 2007-February 2008 in the Great Divide Basin, Wyoming, USA. Open dashes in the inset depicting snowfall amount represent readings during the study period; filled dashes represent the monthly 30-yr average. The shaded (gray) region in the line chart depicts the period during which aerial surveys for sage-grouse were conducted. Data are from the National Oceanic and Atmospheric Administration, National Climate Data Center, Rawlins Wyoming Municipal Airport, Wamsutter, Wyoming.

The predominant historic and ongoing land uses in the study area were domestic livestock grazing and development of energy resources. Infrastructure associated with oil and natural gas development accounted for $94 \%$ of the surface disturbance and $\geq 5 \%$ of the total landscape within the study area. In 2010 there were 4100 oil or natural gas wells within the study area; proposed development is expected to continue until 2025, resulting in an additional 8950 wells within the study area (BLM 2011).

Severe weather conditions characterized the winter of 20072008 in the study area, particularly during December-February (Fig. 2). Snowfall was $46 \%$ above normal, with $58.9 \mathrm{~cm}$ falling during December-February compared to the 30 -yr average of $32.0 \mathrm{~cm}$. Temperature averaged $-4.8^{\circ} \mathrm{C}$ with $70.3 \%$ of days colder than the 30-yr average (Fig. 2). Consistent belowaverage temperature resulted in the persistence of deep snow throughout December-February. Field data collection (described below) was conducted during the severe winter of 2007-2008.

\section{Field Data Collection}

We established 22 aerial survey transects throughout the study area arranged in a continuous zigzag design (sensu Strindberg and Buckland 2004) and spaced at 9-km intervals (Fig. 1). Transect spacing and arrangement reflected an effort to maximize coverage of the landscape within the context of limited financial resources; the zigzag design increased efficiency by eliminating travel time between transects. We surveyed transects by helicopter (Bell 206 Jetranger) flying 50 $\mathrm{km} \cdot \mathrm{h}^{-1}$ at $15-30 \mathrm{~m}$ above ground level on each of three separate events between 10 and 20 February 2008, with each survey event separated by $\geq 3$ days. We recorded the location of 
Table 1. Covariates calculated in a Geographic Information System (GIS; ArcMap 10.0) for potential inclusion in models of resource selection among greater sage-grouse. A description of each covariate is provided in the right-hand column. All data (raster images) were calculated at a resolution of $30 \mathrm{~m}$.

Predominant human modifications of the landscape

Distance to nearest anthropogenic feature
$\begin{aligned} & \text { Distance }(\mathrm{m}) \text { to the nearest anthropogenic feature including roads (paved, improved unpaved, or maintained dirt roads), } \\ & \text { pipelines, well pads, energy-related ancillary features (compressor stations, settling ponds, and buildings), and }\end{aligned}$
residential or agricultural structures (houses, sheds, and barns). Data were heads-up-digitized at a scale of 1:2000 from
20061 -m resolution National Agriculture Imagery Program aerial imagery. This feature was calculated using the Spatial
Analyst/Euclidean Distance tool in ArcMap.

Predominant vegetation in the study area

Average percent shrub $810 \mathrm{~m}, 1590 \mathrm{~m} \quad$ Each cell represented percent shrub averaged across all cells comprising moving windows of 810 or $1590 \mathrm{~m}$ on a side. The data source was the Provisional Remote Sensing Sagebrush Habitat Quantification Products for Wyoming developed by the US Geological Survey. Raster cell values are the estimated percent of each pixel for which the vegetation type is shrub species. Detailed information on development and accuracy of all vegetation layers is in Homer et al. (2012).

Average percent sagebrush $810 \mathrm{~m}$, $1590 \mathrm{~m}$

Each cell represented percent sagebrush (Artemisia spp.) averaged across all cells comprising moving windows of 810 or $1590 \mathrm{~m}$ on a side.

Average percent big sagebrush $810 \mathrm{~m}$, $1590 \mathrm{~m}$

Each cell represented percent big sagebrush (Artemisia tridentata spp.) averaged across all cells comprising moving windows of 810 or $1590 \mathrm{~m}$ on a side.

Average percent Wyoming big sagebrush $810 \mathrm{~m}, 1590 \mathrm{~m}$

Average shrub height $810 \mathrm{~m}, 1590 \mathrm{~m}$

Average percent bare ground $810 \mathrm{~m}$, $1590 \mathrm{~m}$

Each cell represented percent Wyoming big sagebrush (Artemisia tridentata wyomingensis) averaged across all cells comprising moving windows of 810 or $1590 \mathrm{~m}$ on a side.

Each cell represented height $(\mathrm{cm})$ of shrubs averaged across all cells comprising moving windows of 810 or $1590 \mathrm{~m}$ on a side. Raster cell values are the estimated pixel-wide height $(\mathrm{cm})$ of shrub vegetation.

Each cell represented percent bare ground averaged across all cells comprising moving windows of 810 or $1590 \mathrm{~m}$ on a side.

Topographic and other natural features of the landscape

Elevation

Heat load index (HLI)

Slope

Terrain roughness $810 \mathrm{~m}, 1590 \mathrm{~m}$
Elevation $(\mathrm{m})$ calculated from a 10-m resolution digital elevation model (DEM; reclassified to 30-m resolution for analysis).

Rescaling of aspect ( $\theta$; radians) from 0 to 1 oriented northeast to southwest depicting the gradient from coolest to warmest aspect using the equation of McCune and Keon (2002): $\mathrm{HLI}=1-\operatorname{cosine}(\theta-45) / 2$

Steepness (degrees) calculated from a DEM.

An index of terrain roughness calculated as the standard deviation (SD) of elevations from a DEM within a moving window of 810 and $1590 \mathrm{~m}$ on a side. These covariates were calculated using the Spatial Analyst/Local/Cell Statistics tool selecting SD as the overlay statistic. sage-grouse using a hand-held GPS unit (Garmin iQue, Garmin International, Olathe, KS) and ArcPad 7.1 (ESRI, Redlands, CA) software. Departure from the transect to record location data was followed by return to the departure point and continuation of the transect survey.

\section{Covariates for Resource Selection Models}

Using a Geographic Information System (GIS; ArcGIS 10.0, ESRI, Redlands, CA), we calculated covariates (raster or grid data) depicting landscape features that influence behavior of sage-grouse during winter (Doherty et al. 2008; Carpenter et al. 2010). One covariate depicted predominant human modifications of the landscape, six covariates depicted predominant vegetation in the study area, and four covariates depicted topographic or other natural features of the landscape (Table $1)$. We calculated covariates at two scales: within $810 \mathrm{~m}^{2}$ and $1590 \mathrm{~m}^{2}$. These scales have relevance in terms of the biology and management of sage-grouse: landscape-level features play a prominent role in structuring occurrence among shrub-steppe species (Knick et al. 2008), previous research on sage-grouse has shown that covariates summarized at such scales often provide strong inference relative to occurrence patterns (Doherty et al. 2008; Carpenter et al. 2010; Dzialak et al.
2012), and $\theta$ such scales align well with current thinking on management of infrastructure relative to sage-grouse habitat (i.e., $810 \mathrm{~m}^{2}$ and $1590 \mathrm{~m}^{2}$ are a quarter-section and section, respectively; State of Wyoming 2011). We used Spatial Analyst in ArcGIS to extract values from grid cells corresponding to point locations (used and nonused locations; see below) for all covariates. Using SAS 9.2 (SAS Institute, Cary, NC), we natural log-transformed the variable distance to the nearest anthropogenic feature to allow a functional form of the relationship between resource selection and distance that depicted a decreasing magnitude of influence with increasing distance, and we developed and evaluated a quadratic term for vegetation covariates and slope because animals often avoid the lowest and highest values associated with a given landscape feature.

\section{Resource Selection Modeling}

We used an information-theoretic approach (Burnham and Anderson 2002) to quantify resource selection at the landscape level (second-order; Johnson 1980). First, we fitted univariable logistic regression models, implemented in the LOGISTIC procedure in SAS, to select the spatial scale $(810 \mathrm{~m}$ versus 1590 $\mathrm{m}$ as described in Table 1) and functional form of vegetation 
Table 2. Candidate and confidence model sets (confidence model set shaded in gray), number of parameters (K; includes intercept), Akiake Information scores corrected for small sample size $\left(\mathrm{AlC}_{\mathrm{c}}\right)$, difference in $\mathrm{AlC}_{\mathrm{c}}$ scores $(\Delta), \mathrm{AlC}_{\mathrm{c}}$ weights $(W)$, and evidence ratios (highest $\left.w / w_{i} \ldots \mathrm{R}\right)$.

\begin{tabular}{|c|c|c|c|c|c|}
\hline Model $^{1}$ & K & $\mathrm{AlC}_{\mathrm{c}}$ & $\Delta$ & $w$ & $\begin{array}{c}\text { Evidence } \\
\text { ratio }^{2}\end{array}$ \\
\hline Vegetation + anthropogenic & 7 & 214.625 & 0.000 & 0.272 & 1.00 \\
\hline Vegetation + thermal + anthropogenic & 10 & 214.681 & 0.056 & 0.265 & 1.03 \\
\hline Vegetation & 6 & 215.450 & 0.825 & 0.180 & 1.51 \\
\hline Vegetation + thermal & 7 & 216.430 & 1.805 & 0.111 & 2.47 \\
\hline Vegetation + structural + anthropogenic & 10 & 220.725 & 6.100 & 0.012 & 21.12 \\
\hline Vegetation + structural & 9 & 221.054 & 6.429 & 0.011 & 24.89 \\
\hline Global (all covariates) & 11 & 221.702 & 7.077 & 0.008 & 34.42 \\
\hline Vegetation + structural + thermal & 10 & 222.092 & 7.467 & 0.007 & 41.83 \\
\hline Intercept only (no covariate) & 1 & 241.166 & 26.541 & $4.7 \mathrm{E}-07$ & 579767.85 \\
\hline
\end{tabular}

and terrain covariates for potential inclusion in the candidate model set. We retained for further consideration the scale and form of vegetation and terrain covariates with the lowest Akaike's Information Criterion adjusted for small sample size $\left(\mathrm{AIC}_{\mathrm{c}}\right.$; Burnham and Anderson 2002). Then we assessed correlation among retained covariates using the CORR procedure in SAS and eliminated a covariate if correlation with another variable was high (Pearson product-moment correlation $\geq 0.7$ ), retaining the covariate with the lowest $\mathrm{AIC}_{\mathrm{c}}$.

Remaining covariates were structured into a candidate set of models that depicted hypotheses on how landscape features functioned in structuring occurrence (Table 2; Walker et al. 2007; Doherty et al. 2008; Carpenter et al. 2010; Dzialak et al. 2011). We estimated fixed-effects models using logistic regression implemented in the LOGISTIC procedure in SAS; this would be considered a Type I design in which inference is at the population level and individual animals are not identified (i.e., Thomas and Taylor 2006). Covariates were compared at used and available (but presumed unused) locations (Manly et al. 2002). Available locations were established by buffering each transect by $200 \mathrm{~m}$ on each side, then using GIS to generate points randomly within the transect buffer at a ratio of two available locations for each used location (spatially constrained assignment of available location to minimize potential contamination).

In the regression models, we weighted available (nonused) locations based on distance from the transect to minimize the influence of false absences. The weight was the inverse of the probability of detection, developed from the used locations. We used GIS to calculate the perpendicular distance between each used location and the transect. We estimated the probability of detecting a sage-grouse as a function of distance from the transect by fitting detection functions for half-normal models with cosine expansions using the program Distance 5.0 (Thomas et al. 2006). The probability that sage-grouse occupied a location assigned as available increased with distance from the transect (because of decreased detection probability at greater distances), thus the lower weighting farther from the transect. Weighting used locations themselves was not necessary because decreased detection at greater distances was a function of the arbitrary orientation of transects relative to the landscape, and there was no reason to assume systematic bias in landscape features relative to distance from the transect. Further, given the survey method, the seasonal ecology of the species, topographic features of the landscape, and climatic conditions during surveys, it was probable that landscape features (i.e., modeling detection as a function of habitat) had limited influence on detection probability (low, slow aerial surveys of large birds with dark plumage resting on deep snow that largely buried topographic and vegetation features). A detection issue that we could not address, but should nonetheless be noted by readers, is behavior by which sage-grouse burrow in the snow for thermal conservation (Back et al. 1987).

We used $\mathrm{AIC}_{\mathrm{c}}$ difference $(\Delta)$ and Akaike weights $(w)$ to assess and select the most parsimonious RSF model. Using $w$, we calculated importance weights, which provide an estimate of the relative importance of individual covariates in explaining occurrence. We established a confidence set of models that included any candidate model with $w_{i}$ within 10 percentage points of the highest $w$ (Burnham and Anderson 2002). We considered each model in the confidence set a plausible explanation for occurrence. We estimated model-averaged parameter estimates, precision, and confidence limits across the confidence set (Buckland et al. 1997; Burnham and Anderson 2002).

\section{Mapping the Response and Model Validation}

Using Raster Calculator in Spatial Analyst, we created a natural log-transformed grid for the distance covariate, as well as grids depicting a quadratic functional form for vegetation and slope covariates. We applied model-averaged parameter estimates from the confidence set of RSF models to map relative probability of occurrence during severe winter conditions. We used

$$
w(x)=\exp \left(\sum_{k=1}^{K} \beta_{k}^{*} x_{k}\right)
$$

to derive a model-averaged RSF at a resolution of $30 \mathrm{~m}$ where 
Table 3. Model-averaged coefficient estimates, associated precision (SE), and $90 \%$ confidence limits (CL) for covariates within the confidence model set that depicted resource selection by greater sage-grouse during severe winter conditions in a human-modified landscape in the Intermountain West, USA.

\begin{tabular}{lccl}
\hline \multicolumn{1}{c}{ Parameter } & Estimate & \multicolumn{1}{c}{ SE } & \multicolumn{1}{c}{$90 \% \mathrm{CL}$} \\
\hline Intercept & 3.51 & 3.66 & $-2.486-9.505$ \\
Big sagebrush $1590 \mathrm{~m}$ (linear) & 0.022 & 0.256 & $-0.442-0.397$ \\
Big sagebrush $1590 \mathrm{~m}$ (quadratic) & -0.005 & 0.013 & $-0.016-0.025$ \\
Shrub height $810 \mathrm{~m}$ (linear) & 0.054 & 0.092 & $-0.097-0.205$ \\
Shrub height $810 \mathrm{~m}$ (quadratic) & -0.001 & 0.001 & $-0.004-0.001$ \\
Bare ground $1590 \mathrm{~m}$ & -0.079 & 0.039 & -0.143 to -0.015 \\
Heat-load index & 0.353 & 0.499 & $-0.465-1.170$ \\
Distance to anthropogenic feature & 0.148 & 0.109 & $-0.031-0.326$ \\
\hline
\end{tabular}

covariates $k(k=1, \ldots, K)$ have values $x$ (Manly et al. 2002). Next, we partitioned cells comprising the raster surface into quantiles based on cell value and reclassified RSF values based on quantiles to establish 10 ranks of the relative probability of occurrence $(1=$ lowest and $10=$ highest $)$. We validated the predictive map using data from sage-grouse in the study area that were fitted with Global Positioning Systems (GPS) collars approximately $1 \mathrm{yr}$ after the severe winter of 2008 (thus, precluding their use in model development). From the larger GPS location dataset, we extracted locations that corresponded to specific winter storm events during 2009-2010. In general, these winters were not considered severe, so by using locations that corresponded only to severe conditions during storm events we hoped to represent resource selection behavior during conditions that may pose limitations on resource availability. We validated the RSF map by plotting these locations on the map and testing whether the number of locations that occurred within each predicted probability of use rank (1-10) increased monotonically with rank using Spearman rank correlation $(\rho)$ implemented by the CORR procedure in SAS. Animal capture and handling protocols associated with the GPS study were approved by the Wyoming Game and Fish Department (Chapter 33 Permit no. 649).

\section{Occurrence Map Refinement}

During severe winter conditions, snow may accumulate and persist at depths sufficient to render large portions of the landscape unavailable (Gilbert et al. 1970). Given the importance of sagebrush as a source of food and cover for sage-grouse during winter (Patterson 1952; Wallestad et al. 1975; Remington and Braun 1985; Hupp and Braun 1989; Welch et al. 1991), we refined the RSF map to explore how reductions in the availability of sagebrush may affect the spatial pattern of predicted occurrence. In GIS we applied the raster depicting estimated shrub height as a mask by which we rendered all shrubs shorter than $15.2 \mathrm{~cm}$ (6 inches) and $30.5 \mathrm{~cm}$ (12 inches), respectively, unavailable as if covered by snow (see Homer et al. 2009, 2012 for information on how shrub height was estimated). We used Raster Calculator in Spatial Analyst to invoke the statements: Con("shrub_height" $\leq 15.2,1$, "rsf_map") and Con("shrub_height" $\leq 30.5$, 1, "rsf_map"). These commands state: If a pixel comprising the raster depicting shrub height has a value of $15.2 \mathrm{~cm}$ (or $30.5 \mathrm{~cm}$ ) or less, then assign the lowest probability of occurrence to that pixel (1), but if shrubs are taller than $15.2 \mathrm{~cm}$ (or $30.5 \mathrm{~cm}$ ) retain the original RSF value.

\section{RESULTS}

Minimum, maximum, and total (summed) transect length was 12.3, 73.4, and $563.6 \mathrm{~km}$, respectively. We recorded 68 observations of sage-grouse in the study area during aerial surveys. Detection probability ranged from 1.0 on the transect to 0.53 at a perpendicular distance from the transect of $200 \mathrm{~m}$. We estimated location error to be $\leq 100 \mathrm{~m}$ given the slow, low flight protocol, and based on visual examination of locations relative to the field notes and the transect buffer. The Hosmer and Lemeshow goodness-of-fit test showed that the best model showed improved fit $\left(\chi^{2}=13.29, d f=8, P=0.10\right)$ over the global model $\left(\chi^{2}=9.09, d f=8, P=0.33\right.$; Table 2$)$.

Nine models made up the candidate set (Table 2). Importance weights, estimated as the sum of $w$ across the candidate model set, showed that given the necessary vegetation components, distance to anthropogenic features $(0.56)$ was 1.4 times more influential in structuring occurrence than the next most important parameter, heat-load index (0.39), and 14.6 times more influential than elevation, slope, or terrain roughness (0.04). Notably, parameter estimates for slope and terrain roughness were consistently positive across models indicating some level of selection for rough terrain. Four models made up the confidence set (i.e., candidate models with $w_{i}$ within 10 percentage points of the highest $w$; Table 2); parameter estimates for covariates that were common across the confidence set were identical in sign and similar in magnitude. Considering model-averaged parameter estimates (Table 3), sage-grouse selected at the landscape level for an intermediate average percentage of big sagebrush and taller shrubs (within $1590 \mathrm{~m}^{2}$ and $810 \mathrm{~m}^{2}$, respectively) and for aspects that confer a higher heat load (south and southwest). Sage-grouse avoided bare ground and anthropogenic features (Table 3). However, close inspection of the results reveals that avoidance of bare ground and, to a lesser extent, avoidance of anthropogenic features and selection for favorable thermal environments regulated the pattern of occurrence, whereas covariates depicting big sagebrush and shrub height provided little information (sensu Arnold 2010; see Discussion).

We used 714 GPS locations from 17 GPS-collared sagegrouse in the study area to validate the map of predicted occurrence (Fig. 3). These locations corresponded to all winter storm events for which we had GPS data including 23-25 November 2009, 6-8 January 2010, and 18-20 February 2010 (National Oceanic and Atmospheric Administration, National Climate Data Center, Rawlins and Wamsutter, WY, USA). The predictive map validated well with $92.9 \%$ of locations occurring in the high predicted probability of occurrence bins (7-10), 6.2\% occurring in the moderate probability of occurrence bins $(5,6)$, and $0.9 \%$ occurring in the low predicted probability of occurrence bins $(1-4 ; \rho=0.92, d f=18$, $P<0.001)$. Using the raster depicting estimated shrub height as a mask to render shrubs $\leq 15.2 \mathrm{~cm}$ and $30.5 \mathrm{~cm}$, respectively, unavailable to sage-grouse reduced the extent of highest probability of occurrence habitat (bins 9 and 10) to 


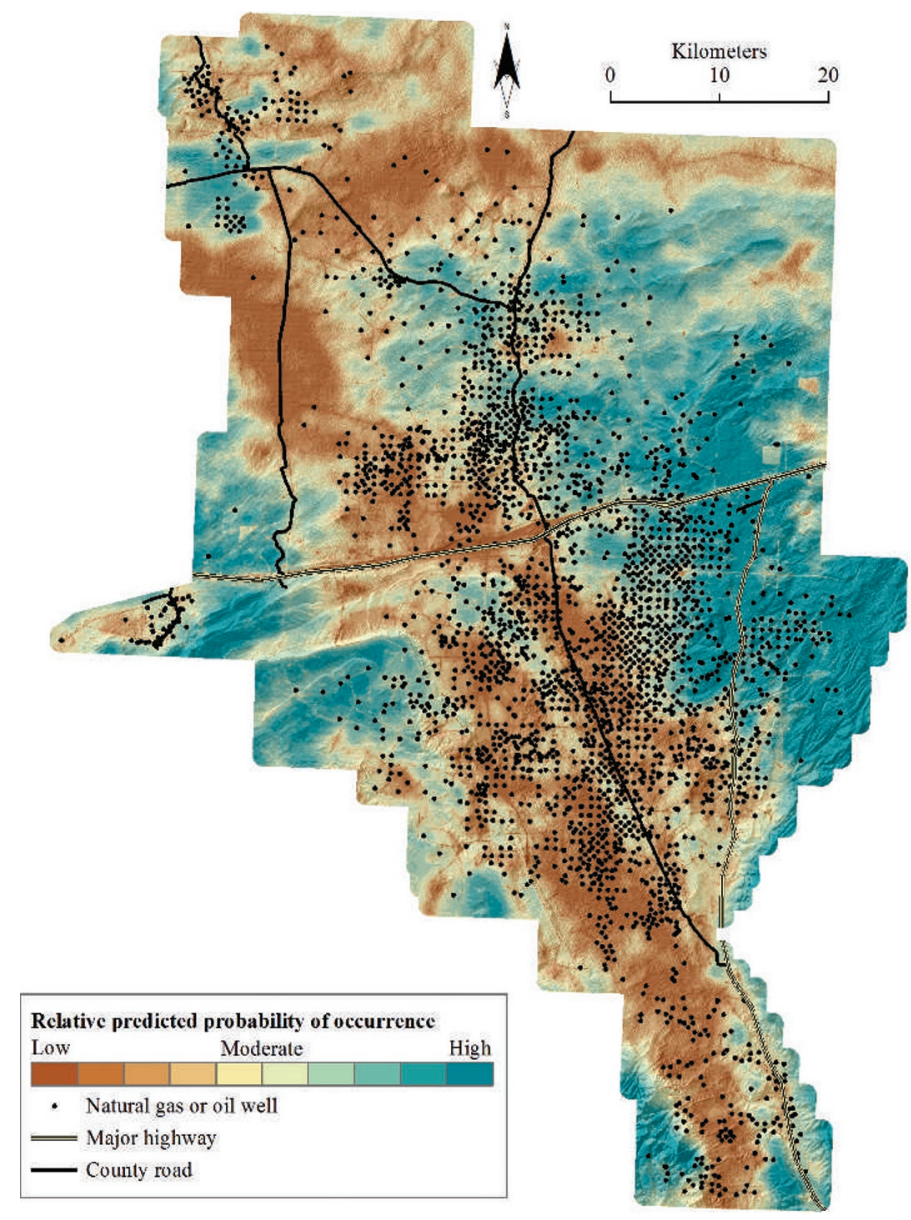

Figure 3. Relative predicted probability of occurrence of greater sagegrouse in the Great Divide Basin, Wyoming, USA, during severe winter conditions.

$17.8 \%$ (Fig. 4A) and $6.9 \%$ (Fig. 4B) of the landscape, respectively (from $20.0 \%$ in the original RSF map; Fig. 3), and depicted the configuration of highest-probability of occurrence habitat as patchily distributed within drainages and topographically variable areas (Figs. 4C and 5).

\section{DISCUSSION}

Conservation of habitat such as severe winter range is a landscape sustainability issue because such habitat functions disproportionately in the persistence of animal populations relative to its spatial extent or frequency of use. Without a place to go when conditions become insupportable, a single climatic event can significantly reduce population size (Barrett 1982; Young 1994), potentially establishing or exacerbating issues that affect conservation in the long term such as genetic bottlenecks, founder effects, or disease (Peterson 2004; Brown et al. 2007). The current lack of information on habitat that buffers populations against climatic variability reflects the challenge of mobilizing resources for data collection during the relatively infrequent and unpredictable occasions when animal resource use reveals such habitat. Indeed, a potential weakness of the investigation we present is that it is based on a single severe winter. However, sampling multiple climatic events (i.e.,

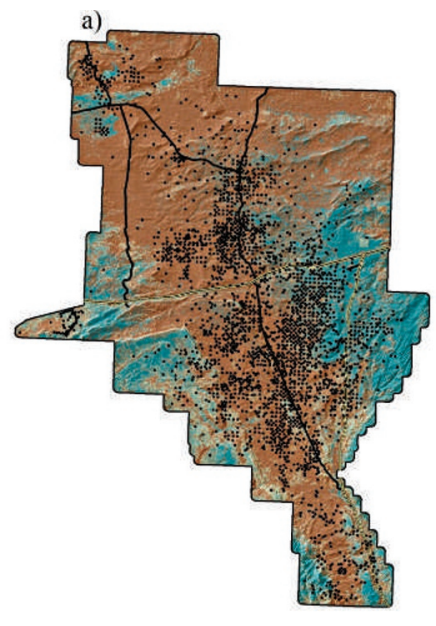

Relative predicted probability of occurrence Low Moderate High

- Natural gas or oil well

Major highway

- County road

c)

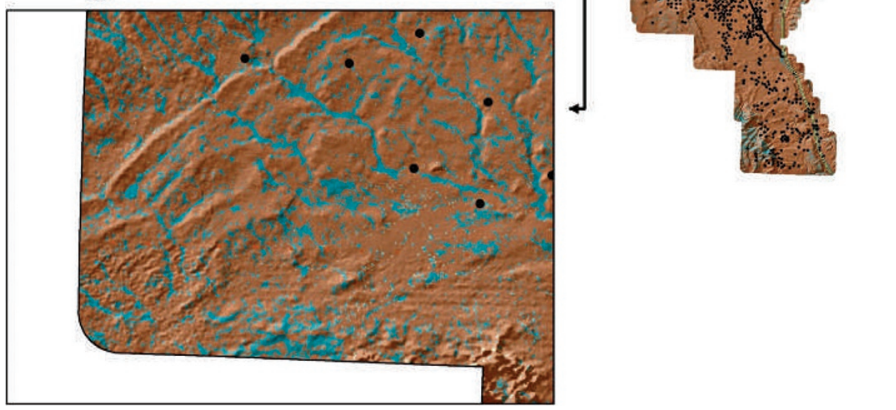

Figure 4. Relative predicted probability of occurrence of greater sagegrouse in the Great Divide Basin, Wyoming, USA, under snow-depth conditions in which shrubs $\leq 15.2 \mathrm{~cm}$ (a) or $30.5 \mathrm{~cm}$ (b) in height are unavailable to sage-grouse as they would be if covered by snow. Panel (c) illustrates the patchy configuration of highest-predicted probability of occurrence habitat under the snow-depth scenario of (b).

severe winters) could require decades, and, if severe conditions greatly narrow the suite of choices available to animals, we would expect any given severe climatic event to be representative of any other event in terms of the constraints placed on animal occurrence. Regardless, information based on a single climatic event provides a basis from which to initiate the process of planning for sustainability, particularly when no other information is available. In places where human modification of rangeland is expanding, such information could be the difference between maintaining stable populations versus population decline and potential listing under federal endangered species provisions (U.S Fish and Wildlife Service 2010).

Mapping predicted occurrence during severe climatic events (Fig. 4) offers spatially explicit guidance for conservation planning. The analysis underpinning spatial predictions of occurrence provides information on mechanisms driving observed patterns. Together, spatial predictions and their underpinning analyses depict where conservation intervention will have its greatest benefit, and provide information on what specific management actions should be undertaken. Results of this analysis indicate that occurrence of sage-grouse during a severe winter was characterized by selection for large patches 
a)

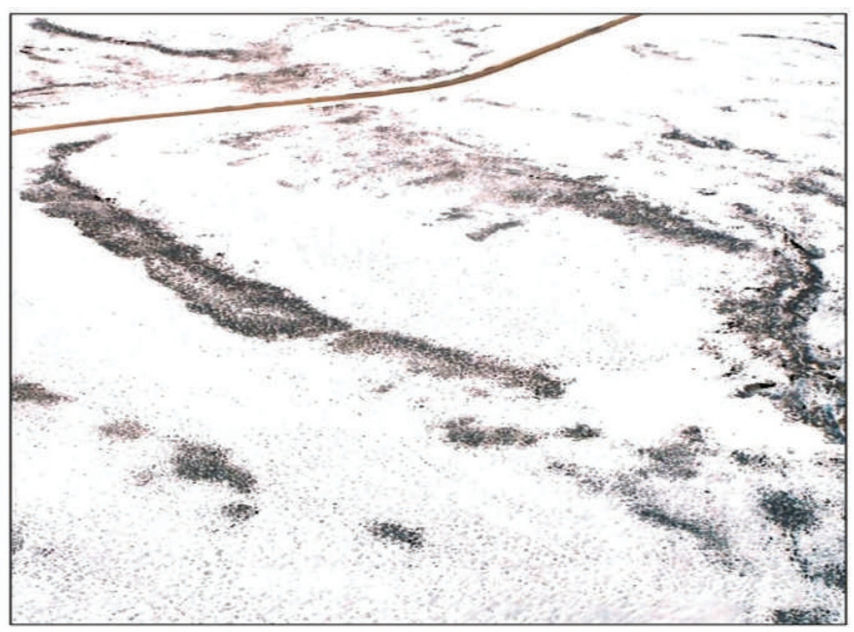

b)

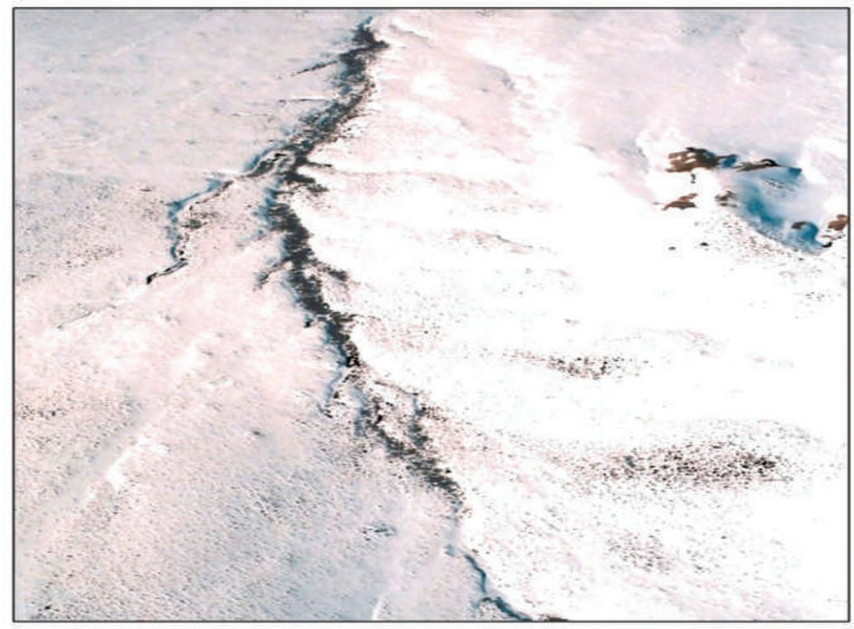

Figure 5. Aerial photographs of habitat patches that were occupied by greater sage-grouse during severe winter conditions in the Great Divide Basin, Wyoming, USA. Panel (a) shows patches of sagebrush exposed from deep snow throughout an area of rough terrain. For reference, the road segment in the top-left portion of the image is approximately $2 \mathrm{~km}$ in length. Panel (b) shows a drainage (approximately $3 \mathrm{~km}$ in length) in which sagebrush remains available within a matrix of deep snow. Photos by J. B. Winstead.

of big sagebrush, tall shrubs, a favorable thermal environment, and avoidance of bare ground and anthropogenic features. A conservation plan based on this information, as a component of a larger strategy that addresses other important habitats (sensu Dzialak et al. 2011), should aim to retain big sagebrush throughout large areas and constrain human activity to the greatest extent feasible within patches that have been identified as critical habitat (Figs. 4C and 5; Walker et al. 2007; Doherty et al. 2008; Harju et al. 2010; Holloran et al. 2010).

It is important to note that, upon close inspection of modelaveraged coefficient estimates and their associated precision, several covariates are considerably more informative than other covariates in terms of which landscape features have the strongest influence on the spatial pattern of occurrence during severe winter conditions (sensu Arnold 2010). Specifically, avoidance of bare ground was a key feature of the behavior of sage-grouse; bare ground offers little to sage-grouse during winter in terms of forage or thermal conservation. Other landscape features of relative importance were roads and wells, which sage-grouse tended to avoid, and south- and west-facing aspects, which likely conferred thermal environments that were more favorable than north or east aspects. Avoidance of human activity appears to be a general feature of winter occurrence among sage-grouse (Doherty et al. 2008; Carpenter et al. 2010; Dzialak et al. 2012). This is notable because the association between human activity and occurrence during nesting and brood-rearing phases appears to be more conditional with sagegrouse sometimes occurring in proximity to anthropogenic features (Aldridge and Boyce 2007; Dzialak et al. 2011). Fidelity to nesting areas may partially explain conditional avoidance of human activity during breeding; sage-grouse tend to be loyal to breeding areas through time even as features of the landscape change, as long as thresholds of change are not exceeded (Harju et al. 2010). Flocking behavior in winter, wherein individuals that show highly risk-aversive behavioral types may influence occurrence patterns among larger groups, could explain the more categorical avoidance of human activity during winter. In the spirit of full reporting and discussion of all model as suggested by Arnold (2010), we note that several models comprising the candidate model set included covariates depicting structural features of the landscape such as terrain roughness (calculated within a $1590 \mathrm{~m}$ window). While models that included terrain roughness did not appear in the confidence set, it is of interest to note that the spatial pattern of occurrence during severe winter conditions reflected selection for rough topography rather than the well-known pattern of selection for flat areas during average winter conditions (Doherty et al. 2008; Carpenter et al. 2010; Dzialak et al. 2012). When conditions are severe, particularly when wind-driven snow is a factor (i.e., drifting; see below), rougher terrain would offer heterogeneity in terms of the accessibility of forage whereas forage resources may be inaccessible, buried in snow, throughout flatter areas.

We refined the RSF map of occurrence using a raster depicting estimated shrub height based on the known importance of available sagebrush (above snow levels; Patterson 1952; Wallestad et al. 1975; Remington and Braun 1985; Hupp and Braun 1989) and on first-hand experience surveying the study area during severe winter conditions (we logged $54 \mathrm{~h}$ of aerial survey time during severe winter conditions). We acknowledge that this refinement is coarse in that it assumes uniform coverage of snow, which, given wind conditions throughout many rangelands, generally does not occur. Nonetheless, the configuration of highest-probability of occurrence habitat as depicted in the refinement (Figs. 4B and 4C) shows striking consistency with photographs of habitat in which sage-grouse were observed (from the helicopter) during severe winter conditions (Fig. 5). Refinement of the RSF using the shrub height brings to bear a hierarchical perspective in which patches of tall sagebrush (Fig. 5) are nested within larger stands of big sagebrush that characterize winter range generally (Eng and Schladweiler 1972; Beck 1977; Hupp and Braun 1989; Doherty et al. 2008). Snow deposition as a function of wind and its effect on resource availability is a key issue that should be acknowledged in any discussion of the occurrence of sage-grouse in winter. Wind is one of the dominant controls of snow accumulation and distribution on rangelands, with deposition patterns being a complex function of highly variable 
wind fields and terrain features (Winstral et al. 2002). Throughout the course of a severe winter on many rangelands, wind-driven snow deposition will have a cumulative negative effect on resource availability because storm/wind events often vary in terms of prevailing direction, and temperatures remain low enough to preclude significant snowmelt. The conspicuous absence throughout the published literature of wind effects in spatial models of winter occurrence among sage-grouse may attest to the challenge of developing and validating an eventbased predictive surface (see Purves et al. 1998; Winstral et al. 2002). Although we currently lack the data for such an undertaking as part of this effort, one practical approach in the future could involve assembling event-based meteorological data in association with terrain data in an effort to develop a predictive surface that contrasts places that "always provide good severe winter habitat" versus places that "could potentially be rendered unavailable depending on the storm event." Accounting for spatial heterogeneity of snow distribution in spatial models of animal occurrence on rangelands should perhaps be commonplace regardless of the severity of the season. We advise that readers keep this issue in mind when interpreting results herein, and when interpreting results of any exercise in which animal occurrence is depicted spatially across snow- and wind-prone landscapes.

\section{IMPLICATIONS}

Management strategies that include identifying and conserving habitat that buffers populations from climate-induced limitation on habitat availability would have general application across taxa and landscape types. Here critical habitat for sagegrouse during severe winter conditions was characterized by an intermediate density of tall sagebrush and other shrubs at the landscape level throughout places where there was little bare ground, a favorable thermal environment, moderately rough terrain, and where there were few anthropogenic features. The mapping tools developed here contribute to rangeland sustainability throughout the study area because they offer spatially explicit guidance for planning human activity in ways that are compatible with conserving sage-grouse under conditions of limited resource availability. Persistent avoidance of human activity among sage-grouse during winter (Doherty et al. 2008; Carpenter et al. 2010; Dzialak et al. 2012) implies that efforts to minimize disturbance of winter habitat during planning phases of development would have tangible conservation benefits including reductions in displacement and effective habitat loss. Another potentially important implication of these results is that topographically variable expanses of sagebrush (i.e., sagebrush on steep or rough terrain, or within drainages) may become increasingly important as the severity of winter conditions intensifies. The distribution of snow will be relatively homogenous throughout flatter areas where sagegrouse tend to congregate under average winter conditions and, at a sufficient snow depth, such areas will be rendered unavailable to sage-grouse. In contrast, steeper and more variable terrain results in considerable variability in snow deposition and thus resource availability. Wind-driven snow deposition and its effect on resource availability is an issue that needs to be addressed quantitatively as part of animal occurrence models on rangelands.

Conserving critical seasonal habitat alone, such as severe winter areas for sage-grouse, is not sufficient as a basis from which to assume long-term population persistence; rather, comprehensive planning that considers habitat needs during all life-history phases is needed (sensu Dzialak et al. 2011). Yet, such critical seasonal habitat is important for many animal populations (Sawyer et al. 2006) because, as a temporary resource bottleneck, it can influence population size even if there is no shortage in resources during more typical climatic conditions. If an increase in climatic variability accompanies global climate change, as has been predicted in some regions (Parmesan and Yohe 2003), place-based, quantitative investigations will be important components of efforts to sustain valued human uses of the land that have not always found compatibility such as development of energy resources and conservation of animal populations and their habitat (Wu 2008).

\section{ACKNOWLEDGMENTS}

We thank F. Blomquist, M. Read, and R. Etzelmiller of the Bureau of Land Management, Rawlins Field Office, F. Blackgoat, C. Hedley, and two anonymous reviewers for guidance and helpful suggestions throughout this effort.

\section{LITERATURE CITED}

AldRidge, C. L., AND M. S. Boyce. 2007. Linking occurrence and fitness to persistence: habitat based approach for endangered greater sage-grouse. Ecological Applications 17:508-526.

ArnoLd, T. W. 2010. Uninformative parameters and model selection using Akaike's information criterion. Journal of Wildlife Management 74:1175-1178.

Back, G. N., M. R. BarRington, and J. K. McAdoo. 1987. Sage grouse use of snow burrows in northeastern Nevada. Wilson Bulletin 99:488-490.

BARRETT, M. W. 1982. Distribution, behavior, and mortality of pronghorns during a severe winter in Alberta. Journal of Wildlife Management 46:991-1002.

Beck, J. L., K. P. ReEse, J. W. Connelyy, And M. B. Lucia. 2006. Movements and survival of juvenile greater sage-grouse in southeastern Idaho. Wildlife Society Bulletin 34:1070-1078.

BЕсK, T. D. 1977. Sage grouse flock characteristics and habitat selection in winter. Journal of Wildlife Management 41:18-26.

BLM. 2011. Continental Divide-Creston natural-gas development project: preliminary draft environmental impact statement. Rawlins, WY, USA: Department of the Interior-Bureau of Land Management Rawlins Field Office. 561 p.

Brown, J. W., P. J. Van Coeverden De Groot, T. P. Birt, G. Seutin, P. T. Boag, and V. L. FriESEN. 2007. Appraisal of the consequences of the DDT-induced bottleneck on the level and geographic distribution of neutral genetic variation in Canadian peregrine falcons, Falco peregrinus. Molecular Ecology 16:327-343.

Buckland, S. T., K. P. Burnham, and S. H. Augustin. 1997. Model selection: an integral part of inference. Biometrics 53:603-618.

BuRnham, K. P., AND D. R. Anderson. 2002. Model selection and multimodel inference: a practical information theoretic approach. New York, NY, USA: Springer. $496 \mathrm{p}$.

Carpenter, J., C. Aldridge, and M. S. Boyce. 2010. Sage-grouse habitat selection during winter in Alberta. Journal of Wildlife Management 74:1806-1814.

Connelly, J. W., and C. E. Braun. 1997. Long-term changes in sage grouse Centrocercus urophasianus populations in western North America. Wildlife Biology 3:229-234.

Connelly, J. W., S. T. Knick, M. A. Schroeder, and S. J. Stiver. 2004. Conservation assessment of greater sage-grouse and sagebrush habitats. Cheyenne, WY, USA: Western Association of Fish and Wildlife Agencies. $610 \mathrm{p}$. 
Doherty, K. E., D. E. Naugle, B. L. Walker, and J. M. Graham. 2008. Greater sagegrouse winter habitat selection and energy development. Journal of Wildlife Management 72:187-195.

Dzialak, M. R., C. V. Olson, S. M. Haruu, S. L. Webb, J. P. Mudd, J. B. Winstead, and L. D. HAYDEN-WING. 2011. Identifying and prioritizing greater sage-grouse nesting and brood-rearing habitat for conservation in human modified landscapes. PLOS ONE 6:e26273.

Dzialak, M. R., C. V. Olson, S. M. Harju, S. L. WebB, and J. B. Winstead. 2012. Temporal and hierarchical spatial components of animal occurrence: conserving seasonal habitat for greater sage-grouse. Ecosphere 3:30.

ENG, R. L., AND P. SchladWEller. 1972. Sage grouse winter movements and habitat use in central Montana. Journal of Wildlife Management 36:141-146.

FEDY, B. C., AND C. L. AldRiDGE. 2011. The importance of within-year repeated counts and the influence of scale on long-term monitoring of sage-grouse. Journal of Wildlife Management 75:1022-1033.

Gilbert, P. F., O. C. Wallmo, and R. B. Gill. 1970. Effects of snow depth on mule deer in Middle Park, Colorado. Journal of Wildlife Management 34:15-23.

Harju, S. M., M. R. Dzialak, R. C. Taylor, L. D. Hayden-Wing, and J. B. Winstead. 2010. Thresholds and time lags in the effects of energy development on greater sagegrouse populations. Journal of Wildlife Management 74:437-448.

Holloran, M. J., R. C. KaIser, AND W. A. Hubert. 2010. Yearling greater sage-grouse response to energy development in Wyoming. Journal of Wildlife Management 74:65-72.

Homer, C. G., C. L. Aldridge, D. K. Meyer, M. J. Coan, and Z. H. Bowen. 2009. Multiscale sagebrush rangeland habitat modeling in southwest Wyoming. Reston, VA, USA: US Geological Survey. Open-File Report 2008-1027. 14 p.

Homer, C. G., C. L. Aldridge, D. K. Meyer, and S. Schell. 2012. Multi-scale remote sensing sagebrush characterization with regression trees over Wyoming, USA; laying a foundation for monitoring. International Journal of Applied Earth Observation and Geoinformation 14:233-244.

Hupp, J. W., AND C. E. BRAun. 1989. Topographic distribution of sage grouse foraging in winter. Journal of Wildlife Management 53:823-829.

JoHNSON, D. H. 1980. The comparison of usage and availability measurements for evaluating resource preference. Ecology 61:65-71.

Knick, S. T., J. T. RotenberRy, and M. Leu. 2008. Habitat, topographical, and geographical components structuring shrubsteppe bird communities. Ecography 31:389-400.

Manly, B. F. J., L. L. McDonald, D. L. Thomas, T. L. McDonald, and W. P. ERickson. 2002. Resource selection by animals: statistical design and analysis for field studies. Norwell, MA, USA: Kluwer Academic Publishers. 240 p.

McAlpine, C. A., L. M. Seabrook, J. R. Rhodes, M. Maron, C. Smith, M. E. Bowen, S. A. Butler, O. Powell, J. G. Ryan, C. T. Fyfe, C. Adams-Hosking, A. Smith, O. Robertson, A. Howes, and L. CattaRino. 2010. Can a problem-solving approach strengthen landscape ecology's contribution to sustainable landscape planning? Landscape Ecology 25:1155-1168.

McCunE, B., AND D. KEON. 2002. Equations for potential annual direct incident radiation and heat load. Journal of Vegetation Science 13:603-606.

Moynahan, B. J., M. S. Lindberg, and J. W. Thomas. 2006. Factors contributing to process variance in annual survival of female greater sage-grouse in Montana. Ecological Applications 16:1529-1538.

Parmesan, C., AND G. Yohe. 2003. A globally coherent fingerprint of climate change impacts across natural systems. Nature 421:37-42.

PatTerson, R. L. 1952. The sage grouse in Wyoming. Denver, CO, USA: Sage Books. $352 \mathrm{p}$.
Peterson, M. J. 2004. Parasites and infectious diseases of prairie grouse: should managers be concerned? Wildlife Society Bulletin 32:35-55.

Purves, R. S., J. S. Barton, W. A. Mackaness, and D. E. Sugden. 1998. The development of a rule-based spatial model of wind transport and deposition of snow. Annals of Glaciology 26:197-202.

Remington, T. E., and C. E. Braun. 1985. Sage grouse food selection in winter, North Park, Colorado. Journal of Wildlife Management 49:1055-1061.

Sawyer, H., M. J. Kauffman, R. M. Nielsen, and J. S. Horne. 2009. Identifying and prioritizing ungulate migration routes for landscape-level conservation. Ecological Applications 19:2016-2025.

Sawyer, H., R. M. Nielson, F. Lindzey, and L. L. McDonald. 2006. Winter habitat selection of mule deer before and during development of a natural gas field. Journal of Wildlife Management 70:396-403.

State of Wroming. 2011. State of Wyoming Executive Department, Executive Order 2011-5, Greater sage-grouse core area protection. Cheyenne, WY, USA: Office of the Governor of Wyoming. $18 \mathrm{p}$.

StrindBerg, S., and S. T. BuckLand. 2004. Zigzag survey designs in line transect sampling. Journal of Agricultural, Biological, and Environmental Statistics 9:443-461.

Thomas, D. L., and E. J. Taylor. 2006. Study designs and tests for comparing resource use and availability II. Journal of Wildlife Management 70:324-336.

Thomas, L., J. L. Laake, S. Strindberg, F. F. C. Marques, S. T. Buckland, D. L. Borchers, D. R. Anderson, K. P. Burnham, S. L. Hedley, J. H. Pollard, J. R. B. Bishop, and T. A. MARques. 2006. Distance 5.0 release 2. Fife, UK: Research Unit for Wildlife Population Assessment, University of St. Andrews.

US FISH AND WILDLIFE SERVICE. 2010. Endangered and threatened wildlife and plants; $12-$ month finding for petitions to list the greater sage-grouse (Centrocercus urophasianus) as threatened or endangered. Federal Register 75:13910-14014.

Walker, B. L., D. E. Naugle, and K. E. DoherTy. 2007. Greater-sage-grouse population response to energy development and habitat loss. Journal of Wildlife Management 71:2644-2654.

Wallestad, R. 0., J. G. Peterson, and R. L. Eng. 1975. Foods of adult sage grouse in central Montana. Journal of Wildlife Management 39:628-630.

Welch, B. L., F. J. WagstafF, AND J. A. Roberson. 1991. Preference of wintering sagegrouse for big sagebrush. Journal of Range Management 44:462-465.

Western Regional Climate Center. 2011. Rawlins FAA Airport, Wyoming (487533): Period of Record Monthly Climate Summary. Available at: http://www.wrcc.dri. edu/cgi-bin/cliMAIN.pl?wy7533. Accessed 11 November 2011.

Wiens, J. A. 1977. On competition and variable environments. American Scientist 65:590-597.

Willams, S. E., AND J. Middleton. 2008. Climatic seasonality, resource bottlenecks, and abundance of rainforest birds: implications for global climate change. Diversity and Distributions 14:69-77.

Winstral, A., K. Elder, and R. E. Davis. 2002. Spatial snow modeling of windredistributed snow using terrain-based parameters. Journal of Hydrometeorology 3:524-538.

Wu, J. 2008. Making the case for landscape ecology: an effective approach to urban sustainability. Landscape Journal 27:41-50.

Young, T. P. 1994. Natural die-offs of large mammals: implications for conservation. Conservation Biology 8:410-418.

Zablan, M. A., C. E. Braun, and G. C. White. 2003. Estimation of greater sage-grouse survival in North Park, Colorado. Journal of Wildlife Management 67:144-154. 